\title{
Ostrze w pierś ,polskiej” zdrady. Satyra i karykatura w służbie groźby w poemacie The Apostate Prince, or Satyr against the King of Poland Richarda Burridge'a (1700)
}

Beata Cieszyńska 
nAPIS Seria XIV 2008

\section{Beata Cieszyńska}

\section{Ostrze w pierś ,ppolskiej” zdrady. Satyra i karykatura w służbie groźby w poemacie The Apostate Prince, or Satyr against the King of Poland Richarda Burridge'a (1700) ${ }^{1}$}

$\mathrm{N}$ Tie pierwszy to i nie ostatni raz satyra brytyjska przywołuje Polskę i polskiego króla. W XVII stuleciu wraz z motywem „co w Polsce, to w Anglii” polskie akcenty pojawiały się tam w kontekście zaostrzającej się walki o władzę między parlamentem a królem, zwłaszcza w pełnym terroru okresie tzw. „spisku papieskiego” (1678-1681)². W podobnej funkcji powrócą one jeszcze w znanym i szeroko komentowanym poemacie alegorycznym Daniela Defoe Dyet of Poland z roku 1705. Do okresu rozbiorów satyra angielska wykorzystywała jednak te motywy, mając częściej na uwadze perspektywę wewnętrzną i/lub przynajmniej geograficznie od Polski bliższą - na przykład celując we Francję, Hiszpanię lub Rzym. W tych wypadkach, nawet wychodząc od konkretnych wydarzeń w Polsce - jak wolna elekcja (zwłaszcza wybór Jana III Sobieskiego), obrady sejmowe, czy tzw. tumult gdański (1678) - podejmowała problematykę de facto brytyjską. Polska „obcość” lub „swojskość” przekładane były na język propagandy i ostrej walki politycznej rodzącego się angielskiego parlamentaryzmu ${ }^{3}$.

\footnotetext{
1 Materiał opracowany w ramach stypendium Fundacji z Brzezia Lanckorońskich przyznanego na kwerendy w bibliotekach brytyjskich.

2 Zob. C. W. Prevote-Orton, Political Satire in English Poetry, Cambridge 1910, chapt. III: Development of Party Satire. W obecnym artykule pomijam gatunki wtórnie satyryczne, o odrębnej poetyce, takie jak np. sztuki teatralne wykorzystujące Polskę jako alegoryczne tho dla politycznych rozgrywek między Stuartami a Parlamentem.

${ }^{3}$ Szerzej o tym zob.: B. Cieszyńska, Swojskość i obcość jako narzędzia wartościowania w daunej satyrze angielskiej o Polsce, w: Wartości między biegunami i między biegunami wartości, red L. Wiśniewska, Bydgoszcz 2004.
} 
Na przełomie wieków XVII i XVIII Brytyjczyków zbulwersowały dwa wydarzenia (wiązane przez nich logicznie), oddziałując na tyle silnie, by zainspirować produkcję satyryczną o Polsce ze „zwiększonym współczynnikiem faktograficznym”. Pierwszym było przejście na katolicyzm elektora saskiego i jego wstąpienie na polski tron jako Augusta II, drugim tzw. wypadki toruńskie z 1724 roku. Twórczość publicystyczno-satyryczna w Wielkiej Brytanii będąca odpowiedzią na te posunięcia obejmowała druki o silnym zabarwieniu emocjonalnym, z przewagą oburzenia i gróźb4

Omawiana satyra Richarda Burridge'a, The Apostate Prince, or Satyr against the King of Poland, wydana w 1700 roku w Londynie jako szesnastostronicowy druk zwarty ${ }^{5}$, wpisuje się w ten podwójny kontekst, trochę jak ogniwo pośrednie między reakcjami na konwersję Sasa a stanowiskiem wobec wypadków toruńskich. Poemat manifestacyjnie przedstawia stosunek krajów protestanckich do Polski kształtowany pod wpływem jej unii personalnej z Saksonią oraz pierwszych wypadków Wojny Północnej. Burridge podjął tu zarówno polityczny, jak i religijny atak na polskiego „zdradliwego" władcę. Jako polski król podległ on w satyrze krytyce totalnej, ukoronowanej groźbą królobójstwa, czekającego go nieuchronnie a zasłużenie. Co zrozumiałe dla tej logiki, jednym z narzędzi satyry i karykatury staje się również opis samej Polski, dyskredytowanej jako licha zdobycz Sasa, nie uzasadniająca tej „najstraszniejszej ze wszystkich zbrodni".

W ataku Burridge'a na Fryderyka Augusta, w tonie zintensyfikowanym oburzeniem dla militarnych działań Sasa w pierwszej połowie 1700 roku, przejawiają się tak religijne, jak i polityczne aspekty jego decyzji o przyjęciu katolicyzmu jako ceny za polską koronę. Satyra ujmuje konwersję Sasa w kategoriach rozwiązań ostatecznych. W calym utworze dominuje obrazowanie spacjalne, wyraźnie nacechowane są kierunki i odległości. Elektor saski przebył zatem drogę z Saksonii do Rzymu, a następnie do Warszawy, wstępując na "chwiejny polski tron”, z którego stopnie wiodą jedynie do upadku. Jak twierdzi narrator, stąd jest już też całkiem blisko do piekła:

Your beads will serve you, as a Scale, to tell

How many Miles it's from Warsaw to Hell [p. 5].

4 Szerzej na temat brytyjskich reakcji na "wypadki toruńskie" zob.: G. Król, Anglia wobec uydarzeń toruńskich 1724 roku, „Zapiski Historyczne” t. 56, 1991; B. Cieszyńska, Polish Religious Persecution as a Topic in British Writing in the Seventeenth and Early Eighteenth Century, w: Britain and Poland-Lithuania Before the Year 1795. Contact and Comparison, ed. R. Unger; with the assistance of J. Basista, Boston-Leiden 2008. Rolę głównego informatora wobec Brytyjczyków odegrał oczywiście dwór pruski.

${ }^{5} \mathrm{Na}$ znanym mi egzemplarzu druku tej satyry znajduje się ręczny nadpisek: „Present”, a następnie, poniżej całości „very severe on him”, ta sama ręka dodała datę dzienną przy roku wydania: "19 July”. Niestety, nie mamy danych na temat właściciela tego egzemplarza, który najpewniej był też komentatorem. 
Oznacza to zarazem „w pół drogi do królobójcy”. Do tego wniosku wiedzie również ostateczna konkluzja satyryka, przewrotnie nawiązująca do glośnej w literaturze angielskiej XVII wieku, a nawet wręcz przysłowiowej postaci Ravaillaca ${ }^{6}$. Był to zamachowiec, który zasłynął tym, iż po zabiciu Henryka IV (1610) nie tylko nie uciekał, jak by się należało spodziewać, ale najspokojniej poczekał na zatrzymanie i straszną kaźń, manifestując przy tym niezmącone zadowolenie. Henryk IV z Navarry pojawia się u Burridge'a jako czytelna analogia, gdyż podobnie jak Sas był on konwertytą, dzięki przejściu na katolicyzm zdobył tron Francji. Smaczku temu porównaniu dodawał fakt, że o zamach dokonany przez Ravaillaca oskarżani byli ojcowie jezuici, nieufnie patrzący na niezbyt gorliwe prześladowania dawnych protestanckich współbraci króla. Naigrywający się z Fryderyka Augusta II Burridge zasugerowal, że w uzyskaniu przez polskiego króla rychłej zapłaty za zdradę wiary i obozu wcale nie będzie konieczna ingerencja protestantów, zdrajca może bowiem zginąć od miecza, z którym igra. Jego własny zamachowiec, niczym Ravaillac, nawet podczas tortur zadowolony z powodu przelania królewskiej krwi, równie dobrze może zostać nasłany przez krwiożerczych i podejrzliwych jezuitów ${ }^{7}$. Wniosek z tego rozumowania nasuwał się taki, że byle morderca lepiej dbałby o swoją duszę, niż wspominany tu polski król:

Your Coronation will be next in Hell $[\ldots]$

That every Deed of Murder would prefer

His noble Soul, to be a Shining Star,

Of Heaven, Heaven would the Murd'rer Greet,

Nay, come Half-way, the Regicide meet [p. 16].

Ostatni cytowany fragment rysuje kolejną imaginatywną perspektywę spacjalną, tym razem wertykalną i w kierunku wstępującym. Oto wznoszący się do nieba pyszny Sas, przyozdobiony koroną, spotyka „niebo w pól drogi”, lecz tu odkrywa, że niebiosa nie jemu wychodzą naprzeciw, nie nad nim się pochylają, lecz w nagrodę nad jego zabójcą.

6 Tekst brzmi:

Were there such as one as Ravillac [sic!],

(That would but Laugh at Tortures on the Rack,

So he could wash his Hands in Royal Gore)

To Stab you, Europe would the fact adore [s. 16].

7 Zob. np. G. Hickes, Ravillac [sic!] Redivivus: Being A Narrative of the Late Tryal of Mr. James Mitchel A Conventicle-Preacher, Who was Executed the 18th of January, 1677 for an Attempt which he made on the Sacred Person of the Archbishop of St. Andrews. To which is Annexed, An Account of the Tryal of that most wicked Pharisee Major Thomas Weir, who was Executed for Adultery, Incest and Bestiality. In which are many Observable Passages, especially relating to the present affairs of Church and State. In a letter from a Scottish to an English Gentleman, London 1678. 
Obok spacjalnego, mamy tu również dość konsekwentnie zarysowane obrazowanie temporalne. Tekst, zgodnie z danymi bibliograficznymi English Short Title Catalogue, miał się ukazać w roku 1700, 3 lata po religijnej i politycznej zdradzie saskiego elektora. Odnosząc się do tych dat, autor podejmuje interpretację numerologiczną: zgodnie $z$ nią Sas rozpoczął budowę swego diabelskiego imperium dokładnie w trzecim roku od zdrady protestanckiej sprawy, jakby tą symboliczną cyfrą chcial ją przypieczętować, spetryfikować i zuniwersalizować. Stąd poeta w dniu 1 czerwca 1700 roku dostrzega początek nowej, piekielnej epoki. Ta „piekielność” przejawia się tu na kilka sposobów: obok piekieł nieuchronnie czekających Sasa po śmierci, mówi się o jego próbach wprowadzenia panowania Szatana na ziemi, a nawet wyrażone zostało przekonanie, że oto przewyższył on swego szatańskiego protektora i zagroził mu. Narrator apeluje do Diabła:
Arouse, ye drousy Imps, and do not Sleep
For, if a Register of time you keep
In Hell, now change the Epocha, and Year
A New Style make, as well as Papists here.
And when Old 'Nick does find such silly Fools,
Who will for Wealth, or Honour sell their Souls,
Much after this same form, and manner, let
The Bond be Sign'd, and hereunto I set
My Hand and Seal, the First of June, N. S.,
In the third Year, since Federick's Wickedness
Revolted from a true Belief, which made
Infernal Markets have but little trade.

Wreszcie autor sugeruje nawet, że Szatan dla wlasnego dobra nie będzie miał innego wyboru, jak tylko osłabić wkrótce siły Augusta II, jak to miał już wcześniej uczynić z księciem Contim [s. 9], gdyż nowy król polski i jego imperium w swej niepohamowanej ekspansji zagrożą wkrótce samemu władcy ciemności.

Poza motywem malowniczo opisanego przymierza z Diabłem, przewyższonym przez polskiego króla, w satyrze pojawia się również dyżurny w takim kontekście topos nieuchronnej ateizacji konwertyty. Zarysowywana przed Fryderykiem Augustem droga — od prawdziwej wiary do katolicyzmu, od katolicyzmu do Szatana, a następnie zwrot ku ateizmowi - występuje w satyrze kilkakrotnie, ukazując nieuniknione konsekwencje ścieżki, na którą wkroczył.

Mimo że emocjonalna, chaotyczna i powracająca po wielekroć do tych samych inwektyw, satyra ta pozwala czytelnie rozdzielić zgromadzoną argumentację na dwie linie. Pierwszą grupę argumentów ośmieszających decyzję Sasa tworzy dyskredytacja katolicyzmu, zwłaszcza jezuitów, których czarna legenda, między innymi za sprawą naszego autora Hieronima Zahorowskiego i jego satyrycznych Monita secreta, w krajach protestanckich święciła 
triumfy już od XVI stulecia. W tej grupie, poza motywami uniwersalnymi, sygnowanymi przez Rzeczpospolitą po prostu jako reprezentanta obozu katolickiego ${ }^{8}$, pojawiają się również wątki typowo polskie, bazujące na polskiej historii i sytuacji, choć niewykraczające poza wiedzę ogólną i typizująca. Jednym $z$ nich jest oburzenie wyrażone nad legendą o św. Stanisławie, patronie Rzeczypospolitej, nazwanym tu „głową polskich świętych”:

To that Communion which does Canonize

Men for nefarious Impieties

(To make their peace with God, invoke the Dead

Stanislaus of Polish Saints the head) [p. 7].

Autor pracowicie, nawet $\mathrm{z}$ rodzajem naukowego poloru, zgromadził tu wszystkie tradycyjne obrazy niszczącej siły katolicyzmu, podsuwając jedyny możliwy wniosek, a zarazem ostatni apel, by Sas opuścił Polskę, zostawiając jej tron innemu straceńcowi, specjalnie do tego wychowanemu:

Leave Poland and let the Dyet choose,

One purposely bred up His Soul to loose [p. 8].

Druga grupa to argumenty polityczno-społeczne. Rzeczpospolita w optyce przyjętej przez satyryka przedstawia się jako niewarta wyrzeczenia się duszy i zdrady Boga. Potwierdza to przede wszystkim prawo wolnej elekcji, które, po pierwsze, uniemożliwia ustalenie tam linii dynastycznej:

For such a Diadem which must not be

Entail'd upon your Line successively [p. 9].

Po drugie zaś, samo w sobie jest aktem karygodnym, gdyż za koronę będącą efektem ludzkiego wyboru musi spaść na Sasa gniew ograniczanego w swych kompetencjach Boga ${ }^{9}$ :

There is approaching a distracted Time,

Wherein the Wrath of Heav'n will soon Rejoyce,

To plague you for the Crown, the People's Choice [p. 10].

\footnotetext{
${ }^{8}$ W tej grupie obok Polaków katolickie bałwochwalstwo reprezentują — poza oczywistymi tu Rzymem i Francją — również Portugalczycy (zob. np. s. 5, przyp. ozn. krzyżykiem).

${ }_{9}$ Argumentacja rozpowszechniona w homiletyce brytyjskiej z czasów Wojen Północnych do tego stopnia, że przyćmiewała w niej czasem cel kazań, jakim była zbiórka pieniędzy na rzecz polskich protestantów. Fakt uczestnictwa szlachty kalwińskiej w tak bezbożnych praktykach jak wolna elekcja bulwersował, w skrajnych wypadkach budząc nawet wątpliwość co do ich prawowierności, a zatem i zasługiwania na pomoc brytyjskich współbraci. Szerzej o tym zob.: B. Cieszyńska, Polish Religious Persecution as a Topic..., op. cit.
} 
Kolejny bezwartościowy aspekt posiadania polskiej, a zatem tylko „wynajętej” korony, to brak stojącej za nią faktycznej królewskiej władzy. W tym kontekście Burrigde interpretuje nieobecność przy Sasie żony jako efekt lęków władcy słabego i całkowicie uzależnionego od poddanych:

Power you've none, for the Republic Rules

As it thinks fit, Crown is but lent by Poles.

Your Queen durst not be there, unless, like you,

She'll head-long damn her Soul, and Body too [p. 12].

Słaba pozycja władcy polskiego - wciąż w kontekście bezwartościowości kroku tak dramatycznego jak konwersja - obejmuje również groźbę ataku na niego samego oraz Saksonię ${ }^{10}, w$ wypadku podjęcia działań niezgodnych $z$ wolą polskich poddanych. Miecz przy jego boku tylko z pozoru jest bronią, będąc w rzeczywistości jedynie bezsilnym symbolem stanu spolecznego:

Because a Gentelman, they let you wear

A Sword, but of your drawing it take care,

For if you offer there to be Uncivil,

They'll drive you, and your Saxons to the Devil.

Przystępując do konkretnego kontekstu podjętej krytyki — pierwszych wydarzeń Wojny Północnej (1700-1721) - narrator zadaje dramatyczne pytanie o to, czy Sas jest już naprawdę całkowicie sterowany przez piekło do spółki z Rzymem. Odpowiedź jest twierdząca. Interpretacja działań zbrojnych i ataku Augusta II na Rygę uzyskuje wykładnię moralno-psychologiczną — nieograniczoną dumę Sasa, oraz religijną, identyfikując jego cel jako przywiedzenie Szwecji (a w tle również Saksonii) do katolicyzmu.

W tym ostatnim duchu skonstruowana została wizja masakr i prześladowań, które zaczną się dokonywać zaraz po tym, gdy polski król opanuje ziemie Rygi i szwedzkie, kiedy to, jak pisze autor: „słodki strumień Dźwiny krwawo splecie się z rzymską furią” [s. 13]. Wizja ta zajmuje dwie kolejne strony satyry, zapełnione scenami zmagań protestanckiego ludu z narzucaną mu obcą i znienawidzoną zwierzchnością jezuicką, z niewolą, dla której autor nie znalazł stosownego porównania w całej historii niewolnictwa. W perspektywie

\footnotetext{
10 Sytuację zagrożonego protestantyzmu w Palatynacie dramatycznie malował na Wyspach Robert Burton, ukazując wzajemną niechęć i brak zaufania w stosunkach Polaków i saksońskiego władcy. Nienawiść i niewiara wobec jego konwersji, odrzucenie przez polską szlachtę jego żony jako jawnej wyznawczyni protestantyzmu oraz podejrzliwość wobec niemieckiego (a więc protestanckiego) wojska miały znamionować postawę Polaków. Ze strony Saksonii natomiast dochodziły sygnały o strachu i niepewności, czy nowa postawa elektora nie oznacza zdrady i początku prześladowań protestantów. Zob. Burton, Martyrs in Flames: or, the History of Popery. Displaying the... cruelties exercised upon Protestants by the Papists... London 1729, p. 117.
} 
politycznej zaatakowani protestanci mogli się spodziewać poddaństwa i ogromnych ciężarów podatkowych, w religijnej zaś — znieważania ołtarzy przez wprowadzanie kultu świętych nieznanych ich ojcom. W tym dramatycznym kontekście pojawia się wyznanie wiary narratora w szwedzki honor, w imieniu którego Ryga wytrzyma obecne ataki.

Wydanie satyry można łatwo powiązać z klimatem Wojny Północnej, rozpoczętej przez Sasa w przymierzu z Rosją 15 lutego 1700. Oczywiście fakt początkowo zwycięskiego uderzenia na protestancką Szwecję przez protestancką Saksonię wiedzioną przez polskiego „przechrzczonego” króla musiał pogłębiać i doprowadzić do statecznej granicy kilkuletnią już niechęć Brytyjczyków. Mimo tak aktualizujących akcentów, wydaje się, iż dynamizm podjętej przez Burridge'a krytyki, inspirowanej zwycięskim pochodem Sasa w początkach wojny północnej, wciąż zdominowany jest przede wszystkim przez krytykę jego konwersji. Tekst utworu wskazuje na dużo wcześniejsze opracowanie zasadniczego tematu, wyraźnie będącego reakcją już na konwersję Sasa. Nasuwa się hipoteza, że satyra została napisana pod bezpośrednim wplywem bulwersującej dla Brytyjczyków i całego protestanckiego obozu postawy Fryderyka Augusta w drodze do stania się Augustem II Mocnym, a więc około lat 1697-1698, jednak z jakiejś przyczyny Burridge jej nie wydał lub nawet nie wykończył. Opublikowana w 1700 roku satyra w początku Wojny Pólnocnej otrzymała impuls do swego wykończenia, ale emocjonalne wykrzyknienia, którymi jest naszpikowana, a które często odnoszą się do aktu konwersji w czasie teraźniejszym, najpewniej zostały zapisane wcześniej, w czasie gdy były wydarzeniem dnia.

Satyra ukazuje również przesunięcie, jakie wraz $z$ wstąpieniem elektora saskiego na polski tron następowało w obozie sił protestanckich - wyłanianie nowego lidera, zdolnego przejąć pałeczkę po Saksonii, obecnie tak rozdartej. To Anglia Wilhelma Orańskiego oraz Jerzego I (a niebawem już, po Unii ze Szkocją, cała Wielka Brytania) powołana została, by w sojuszu z Prusami oraz Szwecją odegrać rolę zbawczyni europejskiego pokoju oraz mścicielki zdrady religii i protestanckiego obozu, obejmując faktyczne przywództwo protestanckiej Europy [s. 13-15]. A zatem, niezależnie od sygnalizowanego na wstępie „wzrostu pierwiastka faktograficznego”, również tu mamy cel ściśle brytyjski i wewnętrzny, oraz bardzo prawdopodobny cel panegiryczno-ekspiacyjny ze strony autora. Być może Burridge sięgnął do tego rozpoczętego wcześniej tekstu w cyklu posunięć koniunkturalnych, posunięć, które wiązały się z eskalacją napięć związanych w samej Anglii z niebezpieczeństwem inwazji katolickiego króla na wygnaniu, Jakuba II Stuarta, dla którego niegdyś Burridge przeszedł na katolicyzm — fakt ten być może wymagał kolejnej manifestacji prawowierności. Stąd taka forma ataku na katolicyzm i afirmacji protestanckiej Anglii, wraz z panegirycznym upostaciowaniem jej króla — przywódcy i wybawcy ${ }^{11}$.

${ }^{11}$ O swym katolicyzmie pisał Burridge dość teatralnie w autobiografii-spowiedzi Religio Medici z 1712 roku. Zob. D. Havenstein, Democratizing Sir Thomas Browne: Religio Medici and Its Imitations, Oxford 1999, p. 74. 
Tezę o wiązaniu około roku 1700 tematu polskiego zdrajcy z perspektywą katolickich prześladowań, zagrażających również Anglii ze względu na niebezpieczeństwo stuartowskiej inwazji, potwierdza inny utwór, $\mathrm{z}$ następnego roku, napisany po śmierci tegoż Jakuba II Stuarta. Mowa o obszernej satyrycznej elegii żałobnej ze zbioru $P o-$ ems on Affairs of State („Poezje o sprawach państwa”), wydawanym kilkakrotnie w XVII i XVIII wieku, a zatytułowanym The British Muse: or Tyranny expos'd. A satyr, Occasion'd by All the Fulsom and Lying Poems and Elegies, that have been Written on Occasion of the Death of the Late King James ${ }^{12}$ („Brytyjska Muza, albo Tyrania ujawniona. Satyra z okazji wszystkich falszywych i kłamliwych wierszy i elegii napisanych z okazji śmierci zeszłego króla Jakuba”) ${ }^{13}$. W utworze tym polski-saski król powraca jako „etatowy” tyran z Północy, prześladowca Saksonii oraz Szwecji ${ }^{14}$. Satyryczna elegia odnosi się do śmierci katolickiego władcy (5 września 1701), już od 1688 roku przebywającego na wygnaniu w pobliskiej Francji i szukającego okazji do odzyskania tronu. Po jego śmierci, spadkobierca i syn, Jakub Franciszek Stuart, jeden z pierwotnych kandydatów Ludwika XIV do polskiego tronu podczas elekcji 1697 roku, zostal przez tegoż ostatniego proklamowany królem Anglii. Wciąż liczni zwolennicy Jakuba II — katolika o dążeniach absolutystycznych, zarzucili Londyn elegiami żałobnymi, mającymi również przygotować pole synowi-następcy. Zaskakujący jest fakt swobodnej kolportacji utworów elegijnych o tak wyraźnie sprzecznym z obecnie panującą władzą wydźwięku politycznym, tym bardziej, że jakobici nazywali w nich zmarłego wygnańca „miłościwie panującym". To właśnie owa bezkarność zaniepokoiła anonimowego republikańskiego pisarza, zmuszając go do gwaltownego protestu w długiej satyrze rozpoczynającej się wezwaniem: „No weeping eyes for Tyrants!” („Niech dla tyrana żadne oczy lez nie ronią!"). Przeciwnie, utwór ogłaszał radość w całym kraju i w Europie, o ile udałoby się obalić wszystkich jej tyranów. W dokonywanym przeglądzie owego „klubu tyranów” poczesne miejsce zajmuje również polski król:

\section{For Tyrants dead no Statues we Erect \\ Or sumptuous fanes with fable Mourning deck'd; \\ No weeping Eyes the joyful Country drown, \\ But all rejoice to hear the Tyrant's gone: \\ For slaves have freedom when the Tyrant's Dead.}

\footnotetext{
12 W: Poems on Affairs of State, Londyn 1703 (wydanie poszerzane kilkakrotnie w XVII i XVIII wieku), s. 354. Interesującego nas tutaj tekstu nie wznowiono jednak w nowoczesnej amerykańskiej edycji Poems on Affairs of State. Augustan Satirical Verse, 1660-1714, vol. 6: 1697-1704, ed. by F. H. Ellis, New Haven and London 1970.

${ }_{13}$ Zob. Poems on Affairs of State, London 1703, op. cit, p. 353-357: The Fall of the House of Orange-Nassau.

${ }^{14}$ Szerzej o obrazie Polski w tej satyrze zob. B. Cieszyńska, Konterfekt Polski i Polaków w satyrze brytyjskiej XVII i XVIII wieku, w: Między Barokiem a Oświeceniem. Sarmacki konterfekt, red. S. Achremczyk, Olsztyn 2006.
} 
Podmiot ostentacyjnie rehabilituje Brutusa i przypisuje mu znacznie mniejszą winę niż tyranowi-Cezarowi. $Z$ takim nastawieniem omawia sytuację na północy Europy i ogłasza Augusta II, polskiego tyrana, godnym zemsty i miecza przeznaczenia. Zyskał on miano „głodnego lwa - tyrana lasów, rządzącego gromadką piskląt”. W ocenie Sasa decydująca okazała się zdrada Boga dla zdobycia korony. Religijny zdrajca nie może mieć już żadnych skrupułów w rządzeniu kijem i batem. Prawdziwym tyranem stał się więc dla protestanckiej Saksonii, którą z „polskich łap” oswobadzać musiał dopiero wielki król Szwecji, w pełni uprawniony do dokonania zemsty:

The Polish tyrant should my vengeance feel, And downwards fall beneath my Fatal Steel.

The Ravenous Lion Tyrant of the Wood

Does Succession for his Ferine Brood;

But no succession crown'd the Polish Bear;

For every Tyrant is elected there.

Ye Polish Slaves, Trepann'd into a Choice,

How ill your Cause suites with your people Voice.

Who could so madly for themselves Elect

A Tyrant, and their Liberties Neglect.

To get a Crown he did forsake his God, And justly proves to Fools a Scourge and Rod.

Great Sweden's King, I'd then Revenge thy Cause, And rescue Saxony from Poland's Claws.

Odmienna opcja oceniająca polskiego króla pociągnęła jednak za sobą w „Brytyjskiej muzie” również inne ukazywanie poddanych „polskiego niedźwiedzia”. Skoro w perspektywie skrajnie republikańskiej niemal każdy władca reprezentuje tyranię, krytyka należy się również samym Polakom, za niezrozumiałe przywiązanie do królewskiej władzy, które nakazywało im obierać króla - i to najczęściej tyrana - choć mogliby się odwrócić od tego reliktu przeszłości. Pogardę republikanina budzi tu nie istota, lecz fakt samego dokonywania elekcji. W apostrofie do „polskich niewolników” z wyboru, w której zaimek „wy” pojawia się w charakterystycznej formie „ye”, podkreślającej pogardliwy dystans między podmiotem a polskimi głupcami, wyrażone jest zdziwienie ich szalonym, przecież wolnym wyborem, który skłaniał się ku tyranowi. Autor pozwala też sobie na ironiczną uogólniającą tezę, iż u Polaków każdy tyran mógłby być obrany królem. Zarazem jednak, jakby z konieczności, w tak źle owocującej elekcji podejrzewa chorobliwy rozdźwięk między głosem społeczności a jej wyborczą reprezentacją.

Zainteresowanie Brytyjczyków poczynaniami dynastii Sasów oraz gotowość do interwencji widać także w późniejszych losach syna Augusta II, przyszłego Augusta III. 
Stał się on kilkakrotnie ofiarą nieudanych prób porwania, które miało zapobiec jego przejściu na katolicyzm i kontynuacji drogi zdradliwego ojca ${ }^{15}$.

Zarysowany powyżej proces literacko-satyrycznego przywoływania Rzeczpospolitej zamyka najsłynniejszy atak satyryczny na Polskę, posunięty aż do groźby zbrojnej interwencji ze strony Wielkiej Brytanii sprzymierzonej z Prusami, nawiązujący do wspominanych na początku wypadków toruńskich. W wyniku represji wywołanych przez zamieszki na tle religijnym doszło tam do ścięcia nie tylko grupy uczestników samych zajść, ale również rajców Torunia (w tym burmistrza), obwinionych przez jezuitów za programową bierność wobec rozruchów. Satyry i komentarze związane z tymi wydarzeniami, w których tumult sprowokowanych protestantów spotkał się z szybką kaźnią wobec osądzonych, przedstawiają pełną gamę postaw wobec Polaków i samego Augusta II. Większość autorów uznała to wydarzenie za spełnienie proroctw z okresu konwersji, nieuniknione następstwo tyranii, którą Sas zaraził się, uległszy katolicyzacji, czyli de facto jezuityzacji. $\mathrm{Z}$ tej przyczyny nie chciał on przeszkodzić wykonaniu wyroków na toruńskich rajcach. Choć rzadko, można było jednak zaobserwować również inną postawę. Wśród zachowanych utworów reagujących na wypadki toruńskie znajdujemy bowiem tekst w pełni apologetyczny wobec Sasa: anonimowy szkocki poemat ${ }^{16}$, ulegający propagandzie mającej na celu podkreślenie niemocy władzy w Rzeczypospolitej, a za tę tragedię obwiniający jedynie samowolnych polskich magnatów ${ }^{17}$.

\footnotetext{
${ }^{15}$ Jak żywotne było to zagadnienie dla Brytanii i Szwecji, wskazuje fakt tak zdecydowanego przerzucenia starań o dekatolicyzację Saksonii na następcę tronu (i przyszłego króla Polski, Augusta III Sasa), który np. w 1711 roku, pod opieką wojewody inflanckiego Józefa Kosa, wyruszył w podróż po Europie. Podczas podróży, w czasie karnawału w Wenecji, Kos udaremnił porwanie królewicza przez agentów brytyjskich. Było to tuż przed rokiem 1712, w którym królewicz, uwalniając się spod wpływu swojej luterańskiej babki Anny Zofii, potajemnie przeszedł w Bolonii na katolicyzm. Szwedzcy i brytyjscy agenci usiłowali zapobiec jego konwersji. Zob. J. Staszewski, August III Sas, Wrocław 1989.

${ }_{16}$ Zob. A Poem upon a Tragedy of Thom, Edinburgh 1725.

17 Szerzej o tym: B. Cieszyńska, Literackie okruchy religijnych peregrynacji Brytyjczyków w Polsce (do początków XVIII wieku), „Napis”, seria 11: Słowa ponad granicami, 2005; zob. też: G. Król, Anglia wobec uydarzeń toruńskich 1724 roku, op. cit., s. 25-46.
} 